\title{
PENGARUH PENGATURAN JARAK TANAM TERHADAP PERKEMBANGAN SERANGAN HAMA DAN PENYAKIT PULAI DARAT (Alstonia angustiloba)
}

\author{
Effect of Plant Spacing Setting to Developing Attack of Pest \\ and Disease of Pulai Darat (Alstonia angustiloba) \\ Asmaliyah ${ }^{1}$ dan/and Tati Rostiwati ${ }^{2}$ \\ ${ }^{11}$ Balai Penelitian Kehutanan Palembang \\ Jl. Kol H Burlian Km 6,5 Puntikayu 179 Telp./Fax. 0711-414864 Palembang \\ Email: asmaliyah_bp2ht@yahoo.com \\ ${ }^{2}$ Pusat Penelitian dan Pengembangan Peningkatan Produktivitas Hutan \\ Jl. Gunung Batu No. 5, Bogor. Telp. 0251-8631238,Fax. 0251-7520005 \\ Naskah masuk : 16 Januari 2014; Naskah diterima : 27 Maret 2015
}

\begin{abstract}
Alstonia angustiloba, one of Pulai species, is a fast growing wich has been developed at Province of South Sumatera. This research was to study the effect of planting spaces on development of pests and diseaseson pulai darat (Alstonia angustiloba) in Kemampo expesimental forest, South Sumatera. The used method was Random Completely Block Design with 6 (six) treatments of planting spacing $(2 \times 2 \mathrm{~m} ; 2 \times 4 \mathrm{~m} ; 3 \times 2 \mathrm{~m} ; 3 \times 2,5 \mathrm{~m} ; 3 \times 3 \mathrm{~m} ; 3 \times 4 \mathrm{~m})$ with 3 replicates. Parameters used were injury symptom, number of attacked plant and score of plant injury severity. The results showed that planting spacing of $3 \times 4 \mathrm{~m}$ is effective spacing to suppress attack Cycnotrachelus sp. and Cephaleuros $s p$. in the third year after planting. The decreasing of attack percentage, beetle pest attack intensity and pathogens were $0.57 \%, 2.48 \%$ and $8.44 \%$ respectively.
\end{abstract}

Keywords: Pest, plant spacing,diseases,pulai darat (Alstonis angustiloba)

\begin{abstract}
ABSTRAK
Alstonia angustiloba (pulai darat) adalah salah satu jenis pulai di antara beberapa jenis Pulai yang banyak dikembangkan di Provinsi Sumatra Selatan. Oleh karena jenis ini termasuk ke dalam jenis cepat tumbuh maka pengembangan jenis berskala besar akan rentan terhadap serangan hama dan penyakit. Tujuan dari penelitian ini adalah untuk mempelajari perkembangan hama dan penyakit pada tanaman pulai darat $A$. angustiloba dengan berbagai perlakuan jarak tanam di Kawasan Hutan Dengan Tujuan Khusus (KHDTK) Kemampo, Sumatera Selatan. Penelitian menggunakan Rancangan Acak Kelompok (RAK) dengan 6 (enam) perlakuan jarak tanam ( 2 × 2 m; 2 x 4 $\mathrm{m} ; 3 \times 2 \mathrm{~m} ; 3 \times 2,5 \mathrm{~m} ; 3 \times 3 \mathrm{~m} ; 3 \times 4 \mathrm{~m})$ dan masing perlakuan diulang 3 kali. Pengamatan dan pengumpulan data dilakukan secara sensus, dengan variabel pengamatan berupa gejala kerusakan, jumlah tanaman yang terserang dan skore tingkat kerusakan tanaman. Hasil penelitian menunjukkan bahwa jarak tanam 3 x 4 m merupakan jarak tanam yang efektif dalam menekan perkembangan hama kumbang Cycnotrachelus sp. dan patogen Cephaleuros sp. pada tanaman pulai darat pada tahun ke tiga setelah penanaman. Kondisi tersebut ditunjukkan oleh terjadinya penurunan persentase serangan sebesar $0,57 \%$ dan penekanan intensitas serangan hama kumbang sebesar $2,48 \%$ serta penyakit patogen sebesar $8,44 \%$.
\end{abstract}

Kata kunci: Hama kumbang,jarak tanam, penyakit, pulai darat (Alstonis angustiloba)

\section{PENDAhuluan}

Pulai (Alstonia spp.) merupakan salah satu jenis tanaman lokal salah satu perusahaan terbatas (PT) di sumatra selatan dan merupakan jenis tanaman yang direkomendasikan untuk digunakan dalam program Gerakan Rehabilitasi
Lahan (GERHAN) di Provinsi Sumatera Selatan. Khusus untuk Sumatera Selatan, pasar kayu pulai sudah terbentuk sejak tahun 1994 bersamaan dengan berdirinya pabrik pensil "slate". Namun salah satu permasalahan yang sering dihadapi dalam sistem penanaman secara monokultur adalah rentan terhadap serangan hama dan 
penyakit yang dapat mengganggu pertumbuhan tanaman bahkan sampai dapat menurunkan produktivitas kayunya.

Kenyataan ini terjadi pada penanaman pulai gading (Alstonia scholaris) yang ditanam secara monokultur di Kabupaten Musi rawas, setelah 1 (satu) tahun di lapangan menghadapi permasalahan hama dengan persentase serangan sebesar \pm $50 \%$, sehingga diprediksi pertumbuhan selanjutnya akan lambat dan pada akhirnya berdampak pada kualitas kayu yang kurang baik (Rostiwati, 2006). Hasil penelitian Asmaliyah et al. (2006) juga menemukan adanya serangan hama yang cukup potensial mengganggu pertumbuhan tanaman pulai darat (A. angustiloba) ke depannya. Kondisi tersebut diakibatkan oleh adanya serangan ulat Clouges glauculalis dan kumbang Cycnotrachelus sp. (Asmaliyah et, 2008). Selain hama ditemukan juga adanya serangan penyakit karat merah atau penyakit bercak daun ganggang (algal leaf spot) (Semangun, 2008) yang disebabkan oleh patogen Cephaleuros sp. (Utami \& Asmaliyah, 2007).

Berdasarkan hasil penelitian tersebut maka tindakan pengendalian penting dilakukan. Tindakan pengendalian yang pernah dilakukan untuk mengatasi permasalahan serangan ulat $C$. glauculalis di pembibitan adalah dengan menggunakan insektisida kimia, namun dalam waktu yang tidak begitu lama, insektisida kimia yang digunakan sudah tidak efektif lagi, diduga kuat ulat C. glauculalis telah resisten terhadap insektisida kimia tersebut.

Cara pengendalian lainnya yang juga pernah dilakukan adalah pengendalian menggunakan insektisida mikroba berbahan aktif bakteri Bacillus thuringiensis dan hasilnya cukup efektif dalam menekan serangan hama C. glauculalis pada tanaman pulai gading (Alstonia scholaris) di lapangan (Asmaliyah et al., 2006). Namun pengendalian tersebut juga beresiko terhadap perkembangan resistensi hama sasaran kalau tidak dilakukan secara tepat dan benar, walaupun peluangnya kecil (Suwahyono, 2013). Untung (2013) melaporkan bahwa Plutellla xylostella strain Lembang telah resisten terhadap bioinsektisida yang berbahan aktif Bakteri Bacillus thuringiensis.

Cara pengendalian alternatif yang dapat dilakukan adalah dengan cara kultur teknis yaitu melalui pengaturan jarak tanam. Pengendalian hama melalui pengaturan jarak tanam mempunyai beberapa keunggulan, selain aman terhadap lingkungan dan makhluk hidup bukan target, murah dan kompatibel dengan banyak cara pengendalian lainnya juga dapat menekan resiko terjadinya resistensi hama sasaran. Cara pengendalian ini dapat menciptakan mikrohabitat sekitar tanaman menjadi tidak menguntungkan untuk reproduksi dan kehidupan organisme hama dan patogen, sehingga diharapkan dapat menekan berkembangnya hama tanaman dan patogen. Perubahan mikrohabitat dapat menguntungkan perkembangbiakan hama-hama tertentu, tetapi dapat juga merugikan bagi perkembangan jenis hama yang lain (Untung, 2013). Menurut Oka (2005); Sumardi \& Widyastuti (2004); Supriati et al. (2011), jarak tanam yang diatur sedemikian rupa selain dapat menurunkan serangan hama dan dapat menekan perkembangan penyakit serta tidak menguntungkan bagi perkembangan patogen, juga dapat memperbesar terjadinya wabah hama dan mendukung berkembangnya patogen. Kemungkinan harus dilihat kasus per kasus tergantung dari species tanaman dan species hama atau penyakit. Penelitian ini bertujuan untuk mempelajari perkembangan hama dan penyakit pada tanaman pulai darat $A$. angustiloba dengan berbagai perlakuan jarak tanam di Kawasan Hutan Dengan Tujuan Khusus (KHDTK) Kemampo, Sumatera Selatan.

\section{METODOLOGI}

\section{A. Lokasi Penelitian}

Penelitian dilakukan di Kawasan Hutan Dengan Tujuan Khusus (KHDTK) Kemampo, yang berdasarkan pembagian wilayah administrasi pemerintahan termasuk Desa Kayu Ara Kuning, Kecamatan Banyuasin III, Kabupaten Banyuasin. Menurut wilayah kerja kehutanan termasuk dalam RPH Kemampo, Dinas Kehutanan Kabupaten Banyuasin, Dinas Kehutanan Provinsi Sumatera Selatan.

\section{B. Bahan dan Alat}

Bahan yang digunakan dalam penelitian ini adalah tegakan tanaman pulai darat tahun tanam 2007, cat, kayu rang, papan, paku, thinner, kertas label, kawat tembaga, tally sheet, dan lain-lain. Sedangkan alat yang digunakan adalah palu, hand counter, kotak plastik, spidol permanen, tali plastik, kamera, alat-alat tulis, dan lain-lain. 


\section{Metode Penelitian}

Penelitian dilakukan pada plot uji jarak tanam yang dibangun tahun 2007 seluas 2,2 ha yang disusun secara eksperimental menggunakan Rancangan Acak Kelompok (RAK). Perlakuan yang diuji adalah jarak tanam yang terdiri dari 6 (enam) taraf yaitu, perlakuan jarak tanam, yaitu 2 x $2 \mathrm{~m} ; 2$ × $4 \mathrm{~m} ; 3$ × $2 \mathrm{~m} ; 3$ × $2,5 \mathrm{~m} ; 3$ x $3 \mathrm{~m}$ dan 3 x 4 $\mathrm{m}$. Setiap perlakuan diulang 3 (tiga kali). Setiap petak pengamatan berukuran $30 \times 30 \mathrm{~m}$, dengan jumlah tanaman per petak pengamatan bervariasi, tergantung jarak tanam.

Metode pengamatan dilakukan secara sensus, yaitu dengan mengamati seluruh tanaman yang terdapat dalam petak pengamatan kecuali 2 (dua) baris dari pinggir. Parameter yang diamati adalah gejala serangan yang tampak pada tanaman yang terserang, banyaknya tanaman yang menunjukkan gejala dan skor tingkat kerusakan tanaman. Data ini digunakan untuk menghitung persentase serangan (P) dan intensitas serangan (I). Waktu pengamatan dilakukan setiap tahun pada bulan Agustus-September mulai tahun 2008 sampai tahun 2010.
Pengukuran persentase serangan hama $(\mathrm{P})$ diperoleh dengan menggunakan rumus:

$\mathrm{P}=\frac{\text { Jumlah tanaman yang terserang dalam suatu petak ukur }}{\text { Jumlah seluruh tanaman dalam suatu petak ukur }} \times 100 \%$

sedangkan pengukuran intensitas serangan secara kuantitatif diperoleh dengan menggunakan rumus:

$$
\mathrm{I}=\frac{\Sigma(\mathrm{ni} \mathrm{x} \mathrm{vj})}{\mathrm{ZXN}} \times 100 \%
$$

Keterangan (Remasks):

I : Tingkat kerusakan tanaman

ni : Jumlah pohon yang terserang dengan klasifikasi tertentu

vj : Nilai untuk klasifikasi tertentu

Z : Nilai tertinggi dalam klasifikasi

$\mathrm{N}$ : Jumlah pohon seluruhnya dalam suatu petak contoh

Sedangkan intensitas serangan secara kualitatif dapat diklasifikasikan menurut kriteria Unterstenhofer, 1963 dalam Djunaedah, 1994, dengan sedikit modifikasi (Tabel 1 dan 2).

Jenis hama dan penyakit yang menyerang

Tabel(Table) 1. Klasifikasi tingkat kerusakan daun yang disebabkan oleh hama (Classification level of leaf damage was caused by pests)

\begin{tabular}{llc}
\hline \multicolumn{1}{c}{$\begin{array}{c}\text { Tingkat kerusakan } \\
\text { (Level damage) }\end{array}$} & \multicolumn{1}{c}{$\begin{array}{c}\text { Tanda kerusakan yang terlihat pada daun } \\
\text { (Signs of damage on leaves) }\end{array}$} & $\begin{array}{c}\text { Nilai } \\
\text { (Score) }\end{array}$ \\
\hline Sehat (Healthy) & - Kerusakan daun $\leq 5 \%$ & 0 \\
Ringan (Light) & - Kerusakan daun antara $5 \%<\mathrm{x} \leq 25 \%$ & 1 \\
Agak berat (Rather heavy) & - Kerusakan daun antara $25 \%<\mathrm{x} \leq 50 \%$ & 2 \\
Berat (Heavy) & - Kerusakan daun antara $50 \%<\mathrm{x} \leq 75 \%$ & 3 \\
Sangat berat (Very heavy) & - Kerusakan daun antara $75 \%<\mathrm{x} \leq 100 \%$ & 4 \\
\hline
\end{tabular}

Tabel(Table) 2. Klasifikasi tingkat kerusakan daun yang disebabkan oleh penyakit (Classification level of leaf damage was caused by the disease)

\begin{tabular}{llc}
\hline \multicolumn{1}{c}{$\begin{array}{c}\text { Tingkat kerusakan } \\
\text { (Level damage) }\end{array}$} & \multicolumn{1}{c}{$\begin{array}{c}\text { Tanda kerusakan yang terlihat pada tanaman } \\
\text { (Signs of damage on leaves) }\end{array}$} & $\begin{array}{c}\text { Nilai } \\
\text { (Score) }\end{array}$ \\
\hline Sehat (Healthy) & Tidak ada serangan/daun sehat & 0 \\
Ringan (Light) & Jumlah daun terserang $\leq 10 \%$ & 1 \\
Agak berat (Rather heavy) & Jumlah daun yang terserang antara $11-30 \%$ & 2 \\
Berat (Heavy) & Jumlah daun yang terserang antara $31-50 \%$ & 3 \\
Sangat berat $($ Very heavy) $)$ & Jumlah daun yang terserang antara $51 \%-80 \%$ & 4 \\
Gagal (Failed) & Jumlah daun yang terserang di atas $80 \%$ & 5 \\
\hline
\end{tabular}


tanaman diidentifikasi di Museum Zoologi-LIPI Bogor.

\section{Analisa Data}

Analisa data dilakukan secara deskriptif kuantitatif terhadap persentase serangan dan intensitas serangan dengan menggunakan grafik untuk melihat perkembangan serangan hama dan penyakit pada setiap pengamatan dan menggunakan analisis sidik ragam dan Uji Duncan.

\section{HASIL DAN PEMBAHASAN}

\section{A. Hasil}

\section{Gejala serangan dan persentase serangan hama}

Berdasarkan hasil pengamatan jenis hama yang dominan ditemukan pada tanaman pulai darat adalah hama kumbang Cycnotrachelus sp. sedangkan hama ulat Clouges glauculalis hanya ditemukan pada pengamatan tahun 2010 dengan jarak $2 \times 2 \mathrm{~m}$ dengan persentase serangan dan intensitas serangan masing-masing $0,28 \%$ dan $0,06 \%$. Berdasarkan kriteria Unterstenhofer (1963) dalam Djunaedah (1994), serangan ulat $C$. glauculalis pada tanaman pulai darat masih termasuk kategori sehat. Sebaliknya serangan kumbang Cycnotrachelus sp. sudah terjadi sekitar 9 (sembilan) bulan setelah tanam. Gejala serangan yang terlihat pada tanaman yang terserang adalah adanya bekas gerekan pada bagian permukaan daun yang berwarna hijau, bagian daun yang diserang kemudian mengering, berwarna cokelat, robek dan gugur, akibatnya daun menjadi berlobang. Daun yang diserang umumnya adalah daun yang terletak paling atas dan masih muda (warna daun masih hijau kekuningan) (Gambar 1).

Hasil analisis sidik ragam terhadap luas serangan atau persentase serangan hama menunjukkan bahwa perlakuan jarak tanam nyata pengaruhnya dalam menekan perkembangan serangan hama kumbang Cycnotrachelus sp. Hasil uji lanjut menunjukkan bahwa perkembangan persentase serangan pada tahun kedua (2008-2009) belum terlihat perbedaan antara jarak tanam rapat dengan jarak tanam yang lebih lebar, baru pada tahun ketiga (2009-2010) terlihat nyata perbedaan antara jarak tanam yang lebih lebar dengan jarak tanam yang lebih rapat (Tabel3).

Tabel 3 menunjukkan bahwa pada penga-matan tahun kedua (2009-2010) perlakuan jarak tanam $3 \times 4 \mathrm{~m}$ paling efektif dalam menekan perkembangan persentase serangan hama kumbang dengan mengalami penurunan sebesar $0,57 \%$ namun tidak berbeda nyata dengan perlakuan jarak tanam $3 \times 3 \mathrm{~m}$, sedangkan perlakuan jarak tanam lainnya mengalami peningkatan. Peningkatan persentase serangan kumbang paling tinggi terjadi pada jarak tanam $2 \times 2 \mathrm{~m}$, yaitu sebesar 5,4 persen, sedangkan paling rendah terjadi pada jarak tanam $3 \times 2,5 \mathrm{~m}$, yaitu sebesar 0,28 persen. Perkembangan persentase serangan hama mulai tahun 2008 sampai tahun 2010 tertera pada Gambar 2.
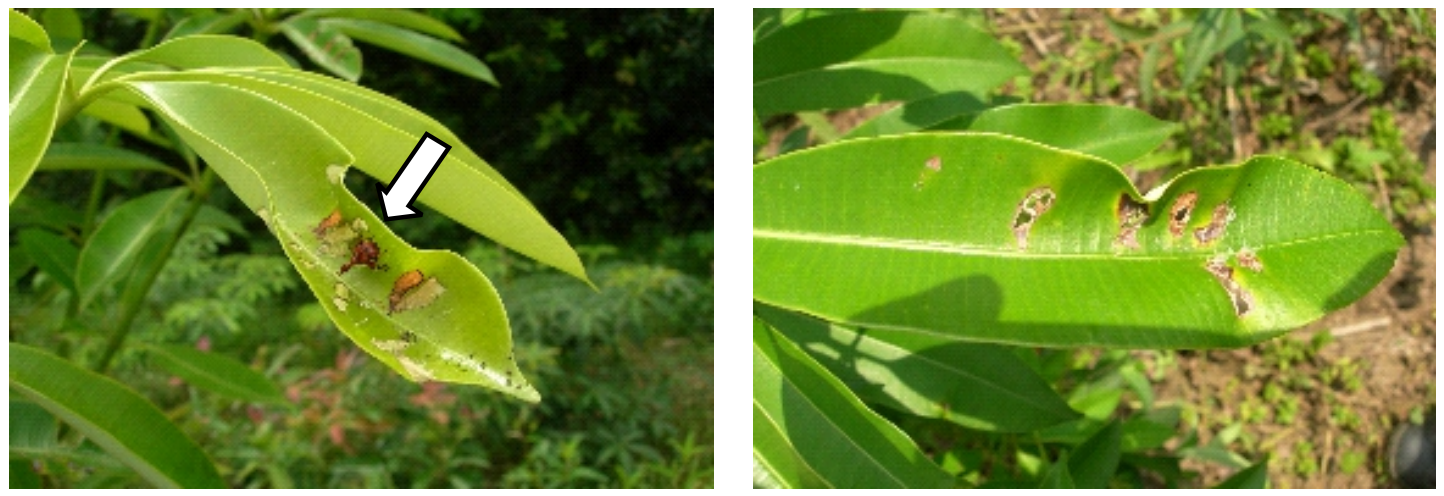

Gambar(Figure) 1. Kumbang Cycnotrachelus sp. (a) dan kerusakannya pada daun (b) (Beetle Cyclotrachelus sp. and its damage on leaves) 
Tabel (Table) 3. Rata-rata perkembangan persentase serangan kumbang Cycnotrachelus sp. pada tanaman pulai darat (A. angustiloba) mulai dari tahun 2008 sampai 2010 (Means of development of beetle attack percentage at pulai from 2008 to 2010)

\begin{tabular}{ccc}
\hline Jarak tanam & \multicolumn{2}{c}{$\begin{array}{c}\text { Perkembangan Persentase serangan } \\
\text { (Development of attack percentage) }(\%)\end{array}$} \\
\hline (Plant spacing) & Tahun 2008-2009 & Tahun 2009-2010 \\
\hline $2 \times 2 \mathrm{~m}$ & $9,82 \mathrm{a}$ & $5,4 \mathrm{~d}$ \\
$2 \times 4 \mathrm{~m}$ & $15,58 \mathrm{~b}$ & $1,81 \mathrm{~b}$ \\
$3 \times 2 \mathrm{~m}$ & $10,20 \mathrm{a}$ & $3,49 \mathrm{c}$ \\
$3 \times 2,5 \mathrm{~m}$ & $15,46 \mathrm{~b}$ & $0,28 \mathrm{ab}$ \\
$3 \times 3 \mathrm{~m}$ & $10,12 \mathrm{a}$ & $0,38 \mathrm{ab}$ \\
$3 \times 4 \mathrm{~m}$ & $10,18 \mathrm{a}$ & $-0,57 \mathrm{a}$ \\
\hline
\end{tabular}

Keterangan(Remarks): $\quad$ angka-angka yang diikuti huruf yang sama menunjukkan tidak ada perbedaan yang nyata pada taraf $5 \%$ (These number are followed by the same letter no significant differences at $5 \%$ level)

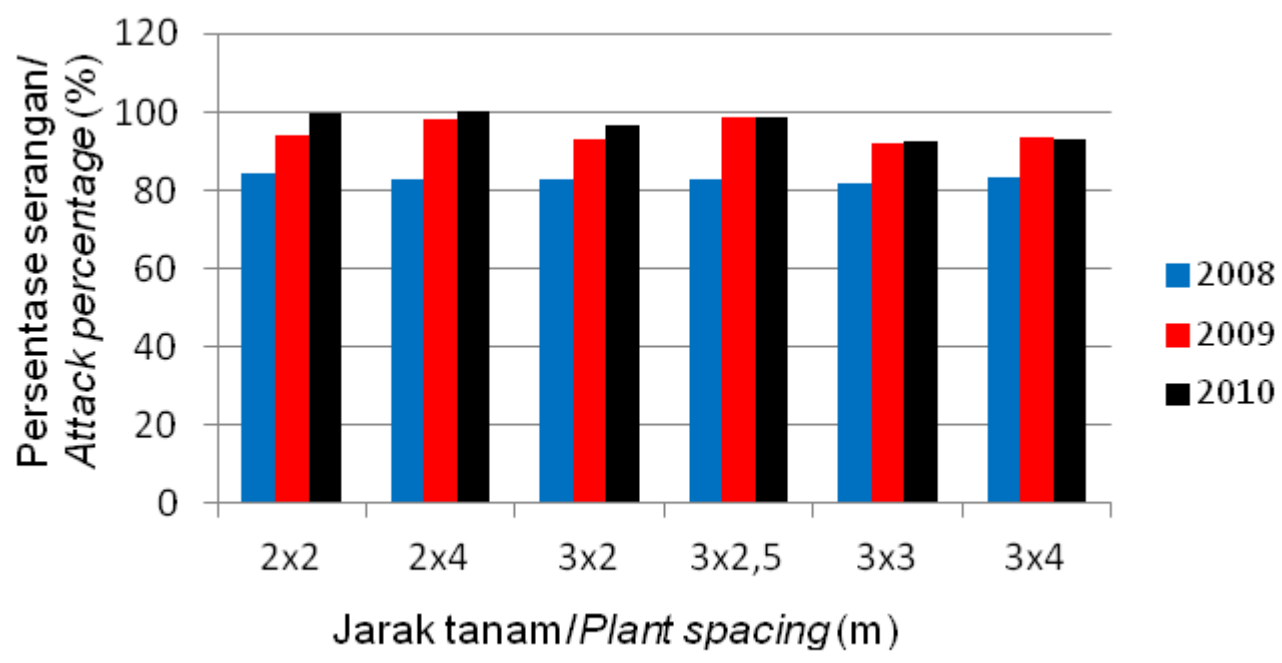

Gambar (Figure) 2. Perkembangan persentase serangan kumbang dari tahun 2008 sampai 2010 (Graphic of development of beetle attack percentage from 2008 to2010)

\section{Intensitas serangan hama}

Hasil analisis sidik ragam terhadap intensitas serangan hama menunjukkan bahwa perlakuan jarak tanam nyata pengaruhnya dalam menekan intensitas serangan hama kumbang Cycnotrachelus sp. Hasil uji lanjut menunjukkan bahwa penurunan intensitas serangan hama pada tahun kedua (2008-2009) antara perlakuan jarak tanam rapat dengan jarak tanam lebih lebar tidak terlihat perbedaannya, sedangkan pada tahun ketiga (2009-2010) penurunan intensitas serangan hama antara jarak tanam rapat dengan jarak tanam yang lebih lebar nyata perbedaannya (Tabel 4).

Tabel 4 menunjukkan bahwa pada pengamatan tahun ketiga (2009-2010) perlakuan jarak tanam $3 \times 4 \mathrm{~m}$ paling efektif dalam menekan perkembangan intensitas serangan kumbang dengan penurunan intensitas serangan paling tinggi sebesar 2,48 persen. Sedangkan penurunan yang paling rendah terjadi pada jarak tanam $2 \times 2$ $\mathrm{m}$, yaitu sebesar 0,66 persen. Perkembangan intensitas serangan hama kumbang pada tanaman pulai tertera pada Gambar 3 . 
Tabel(Table) 4. Rata-rata penurunan intensitas serangan hama kumbang Cycnotrachelus sp. pada tanaman pulai darat (A. angustiloba) mulai tahun 2008 sampai 2010 (Means of decrease of beetle attack intensity at pulai from 2008 to 2010)

\begin{tabular}{ccc}
\hline Jarak tanam & \multicolumn{3}{c}{$\begin{array}{c}\text { Penurunan Intensiats serangan } \\
\text { (Decrease of attack intensity) }(\%)\end{array}$} \\
\hline (Plant spacing) & Tahun 2008-2009 & Tahun 2009-2010 \\
\hline $2 \times 2 \mathrm{~m}$ & $2,92 \mathrm{ab}$ & $0,66 \mathrm{a}$ \\
$2 \times 4 \mathrm{~m}$ & $3,65 \mathrm{~b}$ & $0,84 \mathrm{a}$ \\
$3 \times 2 \mathrm{~m}$ & $2,15 \mathrm{a}$ & $0,82 \mathrm{a}$ \\
$3 \times 2,5 \mathrm{~m}$ & $2,19 \mathrm{a}$ & $0,96 \mathrm{a}$ \\
$3 \times 3 \mathrm{~m}$ & $2,2 \mathrm{a}$ & $0,83 \mathrm{a}$ \\
$3 \times 4 \mathrm{~m}$ & $3,02 \mathrm{~b}$ & $2,48 \mathrm{~b}$ \\
\hline
\end{tabular}

Keterangan (Remark): angka-angka yang diikuti huruf yang sama menunjukkan tidak ada perbedaan yang nyata pada taraf $5 \%$ (These number are followed by the same letter no significant differences at $5 \%$ level)

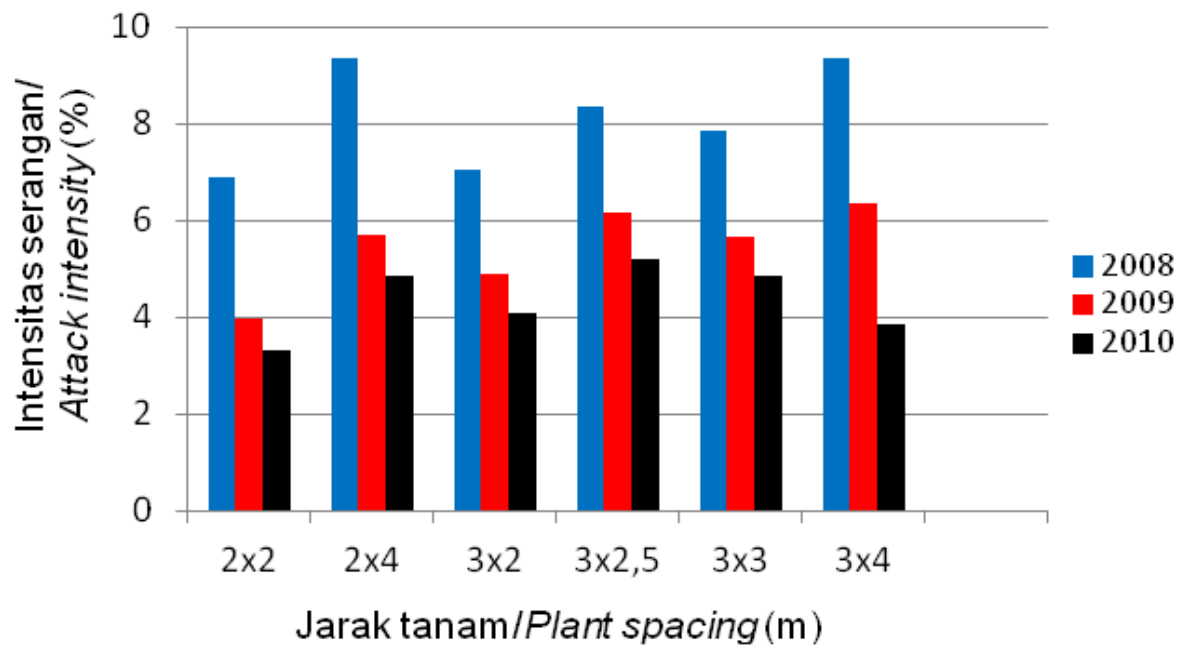

Gambar(Figure)3. Perkembangan intensitas serangan hama kumbang pada tanaman pulai dari tahun 2008 sampai 2010 (Graphic of development of intensity of pest beetle attack at Pulai from 2008 to 2010)

\section{Gejala dan persentase erangan enyakit}

Gejala penyakit bercak daun yang disebabkan oleh ganggang Cephaleuros sp. sudah ditemukan menyerang tanaman pulai darat 1 tahun setelah penanaman. Gejala awal pada daun yang terserang baik daun tua maupun daun muda adalah munculnya bercak-bercak berbentuk bulat, tebal, timbul, dan berbulu yang terdiri dari koloni gang-gang hijau parasit, warnanya mula-mula kelabu kehijauan kemudian berubah men-jadi oranye ke-cokelatan. Setelah beberapa lama daun men-jadi cokelat karena mengering dan kemudian ron-tok.

Hasil pengamatan terhadap persentase serangan penyakit menunjukkan bahwa pada tahun pertama (tahun 2008), hanya perlakuan jarak tanam $2 \times 2 \mathrm{~m}$ yang terserang penyakit bercak daun ganggang, tetapi pada tahun kedua (tahun 2009), semua perlakuan jarak tanam mengalami serangan penyakit bercak daun ganggang dan pada tahun ketiga (tahun 2010), perlakuan jarak tanam terlihat nyata pengaruhnya. Pada jarak tanam $3 \times 3 \mathrm{~m}$ dan $3 \times 4 \mathrm{~m}$ mengalami penurunan persentase serangan yang cukup besar, yaitu masing-masing sebesar 8,70 persen dan 8,44 persen. Sedangkan perlakuan jarak tanam lainnya mengalami peningkatan, paling tinggi adalah perlakuan jarak tanam $2 \times 2 \mathrm{~m}$ sebesar 5,79 persen dan paling rendah adalah jarak tanam $2 \times 4 \mathrm{~m}$ sebesar 2,45 m. Perkembangan persentase serangan penyakit bercak daun pada tanaman pulai darat dapat dilihat pada Gambar 4. 


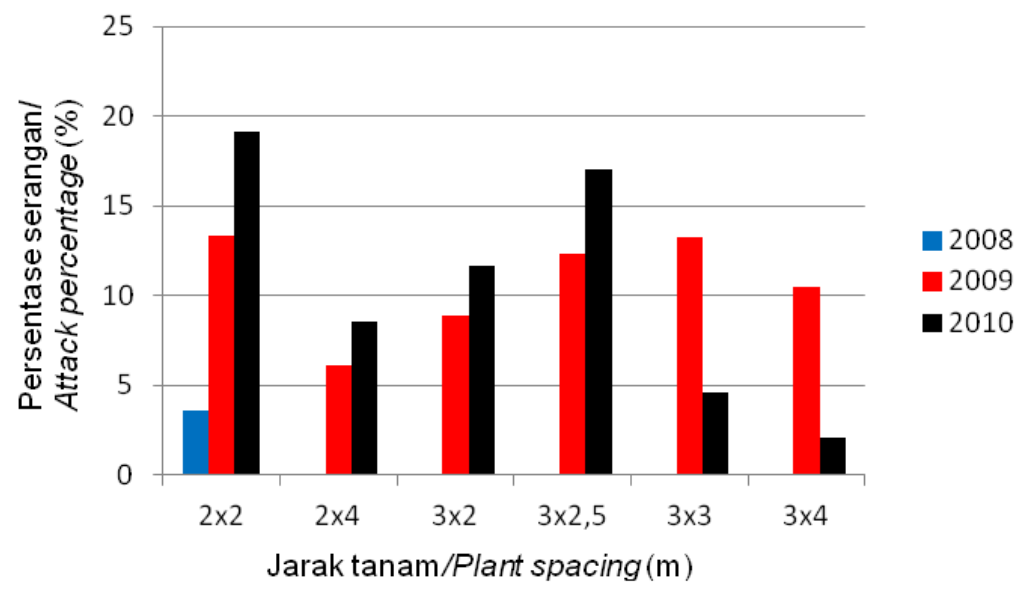

Gambar(Figure) 4. Perkembangan persentase serangan penyakit bercak daun selama 2 tahun (Graphic of development of leaf spot disease attack percentage for 2 year)

Tabel(Table)5. Rata-rata perkembangan persentase serangan penyakit bercak daun ganggang Cephaleuros sp. pada tanaman pulai darat (A. angustiloba) mulai dari tahun 2008 sampai 2010 (Means of development of leaf spot disease attack percentage at pulai from 2008 to 2010)

\begin{tabular}{ccc}
\hline Jarak tanam & \multicolumn{3}{c}{$\begin{array}{c}\text { Perkembangan Persentase serangan } \\
\text { (Development of attack percentage) }(\%)\end{array}$} \\
\hline (Plant spacing) & Tahun $2008-2009$ & Tahun 2009-2010 \\
\hline $2 \times 2 \mathrm{~m}$ & $9,75 \mathrm{abc}$ & $5,79 \mathrm{c}$ \\
$2 \times 4 \mathrm{~m}$ & $6,11 \mathrm{a}$ & $2,45 \mathrm{~b}$ \\
$3 \times 2 \mathrm{~m}$ & $8,86 \mathrm{ab}$ & $2,81 \mathrm{bc}$ \\
$3 \times 2,5 \mathrm{~m}$ & $12,33 \mathrm{bc}$ & $4,66 \mathrm{bc}$ \\
$3 \times 3 \mathrm{~m}$ & $13,26 \quad \mathrm{c}$ & $-8,70 \mathrm{a}$ \\
$3 \times 4 \mathrm{~m}$ & $10,48 \mathrm{bc}$ & $-8,44 \quad \mathrm{a}$ \\
\hline
\end{tabular}

Keterangan(Remarks): $\quad$ angka-angka yang diikuti huruf yang sama menunjukkan tidak ada perbedaan yang nyata pada taraf $5 \%$ (These number are followed by the same letter no significant differences at $5 \%$ level)

Hasil analisis sidik ragam terhadap persentase serangan penyakit menunjukkan bahwa perlakuan jarak tanam nyata pengaruhnya dalam menekan perkembangan persentase serangan penyakit bercak daun ganggang. Hasil uji lanjut pada pengamatan tahun 2009 menunjukkan bahwa

Tabel 5 menunjukkan bahwa perlakuan jarak tanam yang lebih lebar ( $3 \times 3 \mathrm{~m}$ dan $3 \times 4 \mathrm{~m})$ lebih efektif dalam menekan perkembangan persentase serangan penyakit bercak daun dibandingkan jarak tanam yang lebih rapat. Pengamatan tahun 2010, persentase serangan penyakit bercak daun mengalami penurunan pada perlakuan jarak tanam yang lebih lebar, sebaliknya pada jarak tanam yang lebih rapat persentase serangan penyakit bercak daun mengalami peningkatan. persentase serangan penyakit bercak daun antara perlakuan jarak tanam rapat dengan jarak tanam lebih jauh tidak terlihat perbedaan, tetapi pada pengamatan tahun 2010 , persentase serangan penyakit antara jarak tanam rapat dengan jarak tanam yang lebih lebar nyata perbedaannya (Tabel 5).

Peningkatan persentase serangan penyakit paling tinggi terjadi pada jarak tanam $2 \times 2 \mathrm{~m}$ dan paling rendah terjadi pada jarak tanam $2 \times 4 \mathrm{~m}$.

\section{B. Pembahasan}

Jenis hama yang dominan ditemukan pada tanaman pulai darat adalah hama kumbang Cycnotra-chelus sp., sedangkan serangan ulat $C$. glaucu-lalis hanya ditemukan pada pengamatan 
tahun 2010 dengan jarak tanam $2 \times 2$ m dengan persentase serangan dan intensitas serangan masih termasuk kategori sehat. Hal ini menunjukkan bahwa tanaman pulai darat lebih disukai oleh hama kumbang Cycnotrachleus sp. daripada ulat C. glauculalis. Hasil penelitian ini sesuai dengan hasil penelitian sebelumnya yang dilakukan oleh Asmaliyah et al. (2006), menunjukkan bahwa preferensi makan kumbang Cycnotrachelus sp. cenderung pada pulai darat (A. angustiloba).

Berdasarkan pengamatan terhadap persentase serangan dan intensitas serangan hama pada tanaman pulai, maka perlakuan jarak tanam $3 \times 4$ $m$ merupakan jarak tanam yang paling efektif di dalam menekan serangan hama kumbang Cycnotrachelus sp. dibandingkan jarak tanam yang lain. Kondisi tersebut terlihat dari adanya penurunan persentase serangan dan besarnya penurunan intensitas serangan. Diduga faktor yang terkait dengan kondisi tersebut adalah: 1) kemampuan terbang kumbang Cycnotrachelus sp. yang terbatas untuk bermigrasi dari satu tanaman ke tanaman lainnya pada jarak yang lebar; 2) adanya ruang kosong pada jarak tanam yang lebih lebar menjadi faktor pembatas yang dapat mempengaruhi penyebaran dan kelangsungan hidup kumbang; 3) suhu dan kelembaban pada jarak tanam yang lebih lebar tidak mendukung perkembangan patogen; 4) menurunnya populasi hama kumbang, karena iklim mikro dan mikro habitat disekitar tanaman kurang menguntungkan untuk perkembangan kumbang dan tempat peletakan telur; 5) meningkatnya efektivitas musuh alami, sehingga mengurangi kelangsungan hidup hama; 6) meningkatnya vigoritas tanaman, sehingga tanaman menjadi lebih toleran terhadap serangan hama; serta 7) meningkatnya ketahanan tanaman terhadap serangan hama dan penyakit.

Lingkungan yang tidak menguntungkan untuk reproduksi dan kelangsungan hidup organisme hama dan penyakit, dapat menjaga populasi hama dan penyakit selalu pada kepadatan rendah dan menghindari terjadinya ledakan atau meluasnya serangan (Berryman, 1986). Hill (2003) menambahkan bahwa jarak tanam dapat menambah atau meningkatkan efektivitas musuh alami, meningkatkan vigoritas tanaman, mengganggu perilaku hama dalam mencari makanan dan peletakan telur serta mengubah kerentanan tanaman terhadap hama. Kerentanan tanaman terhadap serangan hama dan penyakit tersebut juga dipicu oleh adanya peningkatan kandungan nutrisi daun pada umur- umur tanaman muda seperti hasil penelitian Rostiwati \& Darwiati (2008) bahwa indikator fisiologis adanya peningkatan serangan terhadap daun adalah adanya peningkatan kandungan Nitrogen per luasan daun $A$. scholaris yang cukup tinggi dari tingkat anakan ke tingkat pancang yaitu sebesar 192,31\%.

Menurut Speight \& Wylie (2000), jarak tanam sangat besar pengaruhnya terhadap infes-tasi hama. Hasil penelitian Furuta and Aloo (1994) di Jepang dalam Speight \& Wylie (2000), menunjukkan bahwa pada jarak tanam yang lebih lebar (jarak antar pohon $3 \mathrm{~m}$ ) infestasi hama dan tingkat kematian tegakan muda akibat serangan hama Aphid lebih rendah dibandingkan pada jarak tanam yang lebih rapat (jarak antar pohon 1 $\mathrm{m}$ dan $0,3 \mathrm{~m}$ ). Hasil penelitian Latifian et al. (2012), juga menunjukkan bahwa rata-rata tingkat kerusakan kumbang Oryctes elegans dan kumbang Pseudophilus testaceus pada tanaman kurma lebih tinggi pada jarak tanam kurang dari 5 $\mathrm{m}$ dibandingkan jarak tanam 5-10 $\mathrm{m}$.

Berdasarkan hasil pengamatan terhadap perkembangan persentase serangan penyakit bercak daun ganggang Cephaleuros sp., terlihat bahwa perlakuan jarak tanam $3 \times 3 \mathrm{~m}$ sama hasilnya dengan $3 \times 4 \mathrm{~m}$ merupakan jarak tanam yang baik, sedangkan jarak tanam yang rapat $(2 \times 4 \mathrm{~m}, 3 \times 2 \mathrm{~m}, 3 \times 2,3 \mathrm{~m})$ dapat memicu muncul dan berkembangnya persentase serangan penyakit bercak daun ganggang Cephaleuros sp. Pada jarak tanam yang paling rapat $(2 \times 2 \mathrm{~m})$ terlihat pada umur 1 (satu) tahun setelah tanam sudah muncul serangan penyakit bercak daun ganggang dan serangan penyakit tersebut semakin berkembang seiring dengan bertambahnya umur tanaman karena tajuk antar tanaman sudah saling tumpang tindih. Diduga faktor yang menstimulir kondisi ini adalah kelembaban dan kepadatan populasi tanaman. Jarak tanam yang rapat dan kepadatan populasi yang lebih besar menyebabkan kelembaban disekitar tanaman meningkat. Meningkatnya kelembaban tersebut dapat menyebabkan tanaman menjadi peka terhadap serangan penyakit dan menstimulir berkembangnya patogen serta kurang sesuai untuk persyaratan tumbuh tanaman.

Djafarudin (2000) menyatakan bahwa kebanyakan penyakit dipicu oleh kelembaban yang tinggi. Oleh karena itu, jarak tanam harus diatur sedemikian rupa sesuai dengan kesuburan tanah dan sifat dari tajuk tanaman. Pengaturan jarak tanam yang sesuai dengan jenis tanaman akan berpengaruh baik terhadap pertumbuhan 
dan perkembangan tanaman (Cahyono, 2002), sehingga tanaman lebih toleran terhadap serangan patogen. Saberali (2007 dalam Latifian et al. (2012) juga mengemukakan bahwa kepadatan populasi yang sesuai dapat meningkatkan rata-rata pertumbuhan tanaman, total berat kering dan indek area daun. Jumar (2000) menambahkan rerata suhu udara yang baik untuk pertumbuhan yang optimum adalah sekitar $17^{\circ} \mathrm{C}$, dengan rerata suhu udara minimum $10^{\circ} \mathrm{C}$ dan suhu udara maksimum harian adalah $24^{\circ} \mathrm{C}$ dan rerata kelembaban udara yang tinggi dapat mendukung berkembangnya penyakit yang disebabkan cendawan.

Pengaruh perlakuan jarak tanam ini baru terlihat efeknya setelah tahun ke tiga penanaman atau ketika tanaman pulai darat berumur lebih kurang 3 tahun. Hal ini sesuai dengan pendapat yang dikemukakan oleh Suharti (komunikasi pribadi), bahwa pengendalian hama dan penyakit pada tanaman kehutanan dengan melakukan pengaturan jarak tanam baru bisa terlihat hasilnya setelah tanaman berumur lebih kurang 3 tahun, karena tajuk antar tanaman sudah saling bersentuhan atau tumpang tindih. Pada kondisi ini perubahan iklim mikro (suhu dan kelembaban sekitar tanaman) pada setiap jarak tanam diduga nyata perbedaannya. Hill (2003) menambahkan bahwa salah satu kekurangan dari pengendalian secara kultur teknik, termasuk jarak tanam adalah pengendalian dengan teknik ini membutuhkan perencanaan jangka panjang untuk mengetahui hasil yang terbaik.

\section{KESIMPULAN DAN SARAN}

\section{A. Kesimpulan}

1. Perlakuan jarak tanam yang lebih lebar lebih efektif dalam menekan perkembangan serangan hama kumbang Cycnotrachelus sp. dan serangan penyakit bercak daun ganggang Cephaleuros sp. pada tanaman pulai darat ( $A$. angustiloba).

2. Perlakuan jarak tanam $3 \times 4 \mathrm{~m}$ paling efektif dalam menekan perkembangan hama kumbang Cycnotrachelus sp. pada tanaman pulai darat di tahun ketiga setelah penanaman dengan penurunan persentase serangan sebesar $0,57 \%$ dan penekanan intensitas serangan sebesar $2,48 \%$.

3. Perlakuan jarak tanam yang lebih lebar $3 \times 3 \mathrm{~m}$ dan $3 \times 4 \mathrm{~m}$ lebih efektif dalam menekan muncul dan berkembangnya serangan penyakit bercak daun ganggang Cephaleuros sp. pada tanaman pulai darat di tahun ke tiga setelah penanaman dengan penekanan persentase serangan masing-masing sebesar $8,70 \%$ dan $8,44 \%$

\section{B. Saran}

Jarak tanam yang selama ini diterapkan dalam pola tanam pulai secara monokultur yaitu $3 \times 3 \mathrm{~m}$ disarankan dapat disempurnakan menjadi $3 \times 4$ $\mathrm{m}$.

\section{DAFTAR PUSTAKA}

Anderson, R.F. (1960). Forest and Shade Tree Entomology. New York: John Wiley and Sons,

Asmaliyah, Utami, S. \& Imanullah, A. (2008). Beberapa hama pada tanaman lokal Sumatera Selatan dan alternatif pengendaliannya. Prosiding Seminar Hasil-hasil Penelitian "Mengenal Teknik Budidaya Jenis-jenis Pohon Lokal Sumsel dan Upaya Pengembangannya.11 Desember 2008. Palembang

Asmaliyah, Utami,S. \& Yudhistira. (2006). Preferensi hama kumbang Cycnotrachelus sp. pada pulai (Alstonia spp.). Prosiding Seminar Peran IPTEK dalam Mendukung Pembangunan Hutan Tanaman dan Kesejahteraan Masyarakat. 7 Desember 2006, Kayuagung, OKI.

Asmaliyah, Utami, S., \& Yudhistira. (2006). Efikasi beberapa jenis insektisida terhadap hama Clouges glauculalis pada tanaman pulai darat. Jurnal Penelitian Hutan Tanaman 3 (2).

Badan Penelitian dan Pengembangan Pertanian (Balitbangtan). (2010). Tanam padi jajar Legowo di Lahan Sawah. Buletin Pertanian Edisi Pebruari: 09-32.

Berryman, A.A. (1986). Forest Insect: Principle and Practice of Population Management. Plenum Press-New York and London.

Cahyono, B. (2002). Cara meningkatkan budidaya kubis: Analisis kelayakan secara intensif jenis kubis putih. Yogyakarta: Yayasan Pustaka Nusantara.

Djafarudin. (2004). Dasar-dasar pengendalian penyakit tanaman. Jakarta: Bumi Aksara.

Hill, S.B. (2003). Cultural methods of pest, primarily insect, control. Ecological Agriculture Projects. McGill University. Tanggal akses 5 pebruari 2014 dari: http://eap.megill. 
ca/publication/eap58.

Jumar. (2000). Entomologi pertanian.Jakarta: Rineka Cipta.

Latifian, M., A.A. Rahnama \& Sharifnezhad, H. (2012). Effects of planting on major date palm pests and diseases injuri severity. International Journal of Agriculture and Crop Science (IJACS) Vol. 4 (19).

Oka, I.N. (2005). Pengendalian hama terpadu dan implementasinya di Indonesia. Cetakan Ketiga. Yogyakarta : Gadjah Mada University Press.

Rostiwati, T. \& Winarni, I. (2005). Peluang pengembangan hutan tanaman pulai (Alstonia spp) sebagai jenis dengan penampilan fotosintetik terbaik dan sebagai tanaman obat. Prosiding Seminar Nasional Pembangunan Hutan Tanaman, 18 Nopember 2005, Yogyakarta.

Rostiwati, T. (2006)

. Teknik Silvikultur Jenis Pulai (Alstonia spp). Makalah. Gelar Teknologi Pusat Litbang Hutan Tanama,. 5 Desember 2006 Kabupaten Muaraeni,. Sumatera Selatan,

Rostiwati, T. \& Darwiati W. (2008). Kandungan nitrogen per satuan luas daun sebagai indikator peningkatan serangan hama daun oleh Cloughes glauculalis pada pulai (Alstonia scholaris). Jurnal Penelitian Hutan Tanaman $5(3): 69-78$.

Semangun, H. (2008). Penyakit-penyakit tanaman perkebunan di Indonesia. Cetakan kelima.
Yogyakarta, Gadjah Mada University Press.

Speight, M.R. \& F.R. Wylie. 2000. Insect Pests In Tropical Forestey. CABI Publishing.

Sumardi \& Widyastuti S.M. (2004). Dasar-dasar perlindungan hutan. yogyakarta: Gadjah Mada University Press.

Supriati, L., Nipisa, J. Piter Kulu I. \& Saraswati, D. (2011). Efek perlakuan jarak tanam terhadap perkembangan penyakit Helminthosporium maydis dan Curvularia sp. pada Zea mays saccharata Sturt di tanah gambut pedalaman. Jurnal Ilmiah Agripeat. Jurusan Agroteknologi Fakultas Pertanian Universitas Palangka Raya. http: jurnalagriepat.wordpress.com.

Suwahyono, U. (2013). Membuat Biopestisida. Cetakan I (edisi revisi): Jakarta. Penerbit Swadaya-

Utami, S. \& Asmaliyah. (2007). Pengamatan awal serangan penyakit karat merah pada pulai gading (Alstonia scholaris (L.) R.Br) di KHDTK Kemampo, Kab. Banyuasin, Sumatera Selatan. Prosiding Seminar Hasilhasil Penelitian: Optimalisasi Peran IPTEK dalam Mendukung Revitalisasi Kehutanan", 21 Agustus 2007. Pangkalan balai. Puslitbang Hutan Tanaman.

Untung, K. (2013). Pengantar pengelolaan hama terpadu (Edisi Kedua). Cetakan keenam. Yogyakarta : Gadjah Mada University Press.

Widyastuti, S.M. (2006). Forest Health Monitoring di Hutan Tanaman. Dalam. Prosiding Pengendalian Hama dan Penyakit pada Hutan Tanaman, Jakarta 23 Nopember 2006. Hutan Tanaman: 33 - 39. 